\title{
Engaging Students in Experiential Learning: Texas Integrated Diving and Ecological Studies (TIDES) Laboratory
}

\author{
Stephanie A. Lockwood ${ }^{1}$, Shannon Hill ${ }^{2}$, and Stephanie Randell ${ }^{2}$ \\ ${ }^{1}$ Texas Tech University at Waco, a Higher Education Teaching Site, Department of Biological \\ Sciences, Waco TX 76708 USA \\ ${ }^{2}$ McLennan Community College, Department of Biology, Waco TX 76708 USA \\ (stephanie.lockwood@ttu.edu)
}

\section{Extended Abstract}

The Texas Integrated Diving and Ecological Studies (TIDES) laboratory is a collegiate multi-institutional, international research program designed to engage students through experiential and inquiry-based learning, where students develop and complete novel marine biology projects. Experiential learning is learning from life experiences and inquiry-based learning is where students are an active participant, propose questions and plan and perform research projects (Kolb, 2014). In the TIDES program, students review coral reef research literature, write proposals, develop materials and methods and then execute their research on the Mesoamerican Coral Reef bordering the island of Roatán, Honduras. To guide the development of research topics, during the spring semester, students receive lectures on oceanography, marine ecology, marine invertebrates, coral ecology, coral disease and identification, as well as fish ecology and identification. During each lecture, potential research areas are discussed. Previous research students return to speak with current students about their research topic, results and fieldwork experiences. In conjunction with traditional coursework, students become open water dive certified, receive lectures on marine field techniques and boat etiquette.

Inquiry-based learning begins as students form groups, based on research interests, and begin formulating research goals. Each week, students meet with the professors and discuss progress on research development. Students receive guidance on research proposals, methodology and materials. An exam is given over marine lecture concepts and fieldwork skills exams are tailored to each group's target species. For example, if a group is researching coral disease, they must be able to identify all coral disease and coral species, in addition to a modest list of non-focal species, such as fish, as they are common in the environment and will likely be encountered. Alternatively, if a group was researching fish diversity, they would need to identify all fish species and identification of the non-focal species would include a few select coral species. The following is a list of some of the 2019 student research projects:

- Macroorganisms within the Spongocoels of Callyspongia vaginalis, C. plicifera and Xestospongia muta on the Mesoamerican Reef in Roatán, Honduras

- $\quad$ Prevalence and Abundance of Dark Spot Syndrome on Starlet Corals on the Mesoamerican Barrier Reef in Roatán, Honduras

- $\quad$ Fish Assemblages of the Mesoamerican Barrier Reef, in Roatán, Honduras

- Boulder Coral Abundance and Disease Prevalence in Association with Spirobranchus giganteus in Roatán, Honduras

- Microplastic Loading in the Sediment of Mesoamerican Reef in Roatán, Honduras

At the end of the semester, we travel to the Roatán Institute for Marine Science (RIMS) at Anthony's Key Resort on the island of Roatán, Honduras, where students execute their proposed research (RIMS, 2018). The first few dives acclimate students to the marine environment and diving with research equipment. Typically, we have two research dives per day, with evenings dedicated to data entry. Four to five dive sites are visited twice during the trip. Students attend lectures by the Roatán Institute for Marine Science educator on dolphins and sea turtles, after which students snorkel with dolphins. 
For added service efforts, in 2018 and 2019, we participated in a special dive to a coral nursery, where students participated in coral reef restoration efforts at RIMS. In 2019, a fund raiser was conducted, and we were able to purchase eight coral trees to aid with the restoration efforts at RIMS. The SOL International Foundation also has a Roatán Project designed to help improve the quality of life for the children on Roatán (SOL, 2018). We were introduced to SOL several years ago, and each year students take up a collection of needed goods to donate to the children of SOL.

Upon returning, students analyze their data, thereby honing their quantitative and critical thinking skills, and develop research posters, outlining their projects and conclusions. Many students present these posters and give oral presentations at various research conferences throughout the year (e.g. MCC Scholar Day, Texas Academy of Science, Texas Tech Annual Biological Symposium). Conference attendee feedback has been positive, and many have expressed surprise that undergraduate students developed and executed such challenging and compelling research projects. An impressive number of our TIDES students have won top awards at a variety of research conferences, and in 2018 our first student-led manuscript was published (Kroll et al., 2018). Many of our students go on to graduate or medical school. During the admission interviews, several students reported being asked about their TIDES research. The TIDES research experience is something the students will not forget, and it is something they can use to further their career goals. As many universities and colleges are developing $2+2$ relationships with community colleges, this program could serve as a model for other multi-institutional undergraduate research programs.

Keywords: marine biology, coral reef research, study abroad, inquiry-based learning

Link to Original Poster File: https://doi.org/10.37590/able.v41.poster73

\section{Cited References}

Kolb DA. 2014. Experiential learning: experience as the source of learning and development. 2nd Ed. Hoboken: Pearson FT Press. 416pp.

Kroll ML, Rodriguez BA, Edie AC, Phelps KL, Hamilton DE, Randell SM, Lockwood SA. 2018. Poriferan Abundance is Negatively Associated with Coral Health in the Mesoamerican Reef. Texas Journal of Science 70(1): Article 7.

Roatan Institute for Marine Science (RIMS). 2018. Roatan Institute for Marine Sciences: Caribbean Marine Laboratory. https://www.roatanims.org/.

SOL International Foundation. 2018. SOL International: The Roatan Project. https://www.solroatan.org/.

\section{Mission, Review Process \& Disclaimer}

The Association for Biology Laboratory Education (ABLE) was founded in 1979 to promote information exchange among university and college educators actively concerned with teaching biology in a laboratory setting. The focus of ABLE is to improve the undergraduate biology laboratory experience by promoting the development and dissemination of interesting, innovative, and reliable laboratory exercises. For more information about ABLE, please visit http://www.ableweb.org/。

Advances in Biology Laboratory Education is the peer-reviewed publication of the conference of the Association for Biology Laboratory Education. Published articles and extended abstracts are evaluated and selected by a committee prior to presentation at the conference, peer-reviewed by participants at the conference, and edited by members of the ABLE Editorial Board. Published abstracts are evaluated and selected by a committee prior to presentation at the conference.

\section{Citing This Article}

Lockwood SA, Hill S, Randell S. 2020. Engaging students in experiential learning: Texas Integrated Diving and Ecological Studies (TIDES) laboratory. Article 73 In: McMahon K, editor. Advances in biology laboratory education. Volume 41. Publication of the 41st Conference of the Association for Biology Laboratory Education (ABLE). https://doi.org/10.37590/able.v41.extabs 73 
Compilation (C) 2020 by the Association for Biology Laboratory Education, ISBN 1-890444-17-0. All rights reserved. Nopart of this publication may be reproduced, stored in a retrieval system, or transmitted, in any form or by any means, electronic, mechanical, photocopying, recording, or otherwise, without the prior written permission of the copyright owner.

ABLE strongly encourages individuals to use the exercises in this volume in their teaching program. If this exercise is used solely at one's own institution with no intent for profit, it is excluded from the preceding copyright restriction, unless otherwise noted on the copyright notice of the individual chapter in this volume. Proper credit to this publication must be included in your laboratory outline for each use; a sample citation is given above. 